\title{
Codium (Chlorophyta) species presented in the Galápagos Islands
}

\section{Las especies del género Codium (Chlorophyta) presentes en las Islas Galápagos}

\author{
Max E. Chacana ${ }^{1}$, Paul C. Silva ${ }^{1}$, Francisco F. Pedroche ${ }^{1,2}$ and Kathy Ann Miller ${ }^{1}$ \\ 'University Herbarium, University of California, Berkeley, CA 94720-2465. USA \\ ²Depto. Ciencias Ambientales, Universidad Autónoma Metropolitana, Unidad Lerma, Estado de México, 52007. México \\ e-mail: fpedroche@correo.ler.uam.mx
}

Chacana M. E., P. C. Silva, F. F. Pedroche and K. A. Miller. 2016. Codium (Chlorophyta) species presented in the Galápagos Islands. Hidrobiológica 26 (2): $151-159$.

\begin{abstract}
Background. The Galápagos Islands have been the subject of numerous scientific expeditions. The chief source of information on their marine algae is the report published in 1945 by the late William Randolph Taylor on collections made by the Allan Hancock Pacific Expedition of 1934. Prior to this work, there were no published records of Codium from the Galápagos. Taylor recorder six species of Codium of which $C$. isabelae and $C$. santamariae were new descriptions. Goals. On the basis of collections made since 1939, we have reviewed the registry of Codium in these islands. Methods. Comparative analysis based on morphology and utricle anatomy. Results. Codium isabelae and $C$. santamariae are combined under the former name. Records of $C$. cervicorne and $C$. dichotomum also are referred to $C$. isabelae, those of $C$. setchellii are based partly on representatives of $C$. picturatum, a recently described species from the Mexican Pacific, Panama, Colombia, and Hawaii, and partly on representatives of a species similar if not identical to $C$. arabicum. The presence of C. foveolatum is corroborated. Codium fernandezianum, which was also reported by Taylor from the mainland of Ecuador, has been collected on Isla Santa Cruz. Conclusions. Five species of Codium are recognized from Galápagos Islands: $C$. arabicum, C. fernandezianum, C. foveolatum, C. isabelae and C. picturatum.
\end{abstract}

Key words: Codiaceae, Colon archipelago, morphology, taxonomy.

\section{RESUMEN}

Antecedentes. El archipiélago de las Galápagos ha sido objeto de numerosas expediciones científicas. La fuente principal de información, sobre algas marinas en estas islas, es la expedición de la Allan Hancock realizada en 1934 y cuyos resultados fueron comunicados por William Randolph Taylor en 1945. Previo a este trabajo, no existían registros publicados de especies del género Codium para las Galápagos. Este autor reconoció seis especies, de las cuales $C$. isabelae y $C$. santamariae fueron descritas como nuevas para la ciencia. Objetivos. Con las colecciones conservadas desde 1939, se presenta la diversidad específica actual del género Codium para estas islas. Métodos. Estudios comparativos de morfología y anatomía utricular. Resultados. Como resultado, Codium isabelae y $C$. santamariae se conjuntan bajo el nombre de la primera especie. Registros previos, bajo las denominaciones de $C$. cervicorne y $C$. dichotomum también son referidas a $C$. isabelae; aquellos considerados como $C$. setchellii están basados parcialmente en representantes de $C$. picturatum, una especie, descrita hace poco, proveniente del Pacífico mexicano, Panamá, Colombia y Hawái, otra parte corresponden a una especie, similar mas no idéntica: $C$. arabicum. Se corrobora la presencia de $C$. foveolatum. Codium fernandezianum, que fue registrada también por Taylor para la costa de Ecuador, ha sido recolectada en Isla Santa Cruz. Conclusiones. Cinco especies del género Codium se reconocen como presentes en las Islas Galápagos: C. arabicum, C. fernandezianum, C. foveolatum, C. isabelae y C. picturatum.

Palabras clave: Archipiélago Colón, Codiaceae, morfología, taxonomía. 


\section{INTRODUCTION}

The Galápagos Islands, known officially as the Archipiélago de Colón, straddles the Equator about $960 \mathrm{~km}$ west of the coast of Ecuador. They comprise six relatively large islands, nine islets, and numerous rocks; they represent an area of $800 \mathrm{~km}^{2}$. All are volcanic with lava varying in age, including some from active volcanoes. Tomas de Berlanga, Bishop of Panama, while in route to Peru, discovered them in 1535. He named them "Las Islas Encantadas", but there were few visitors to be enchanted during the ensuing three centuries. Although evidence of pre-Spanish habitation has been found, no one was present to greet the bishop. Spanish voyagers passed through the islands in the late 16th century, followed by buccaneers in the 17th and 18th centuries, giving way to whalers and seal-hunters in the 19th century. No country claimed the islands until Ecuador did so in 1832, soon after seceding from Colombia. The Galápagos Islands were brought to the attention of the scientific world by Charles Darwin's publication of the observations that he had made while serving as naturalist on board the brig "Beagle" under the command of Robert Fitzroy. The voyage began in 1831 and ended in 1836, with six weeks of 1835 spent in the archipelago. The adaptive radiation filling several ecological niches displayed by the finches (Geospizinae), the subspecific differentiation between islands displayed by the giant tortoises (Geochelone elephantopus), and the total absence of amphibians were just part of the extraordinary picture that prompted the gestation of the Darwinian theory of evolution.

Darwin holds the distinction of having introduced the first Galápagos alga to the scientific community, an encrusting coralline dredged from a depth of 12 fathoms by the "Beagle". This specimen (Darwin 3251) was sent to William Henry Harvey at Trinity College, Dublin, who identified it reluctantly as Melobesia calcarea (Pallas) Harvey, a name of uncertain application (Harvey 1849: 110). Lemoine (1929: 56) suggested possible determinations for this specimen, but to our knowledge a present-day specialist has not examined it. Although seaweeds were not as enchanting to the naturalists of subsequent expeditions as finches, tortoises, iguanas, or blue-footed boobies, a few were collected by the U.S. Coast Survey vessel "Hassler" in 1872 and the U.S. Bureau of Fisheries vessel "Albatross" in 1888. Except for Lithophyllum farlowii Heydrich (1901) and Goniolithon frutescens f. galapagense Foslie (1907), these algae were not published on until much later (Taylor, 1945).

The Italian corvette "Vettor Pisani" visited the Galápagos in March 1884 and returned with a few algae (Piccone 1886, 1889). The HopkinsStanford Expedition of 1898-1899 produced about 30 records (Farlow 1902; Foslie 1907). In 1924 Cyril Crossland, a member of the staff of the Saint-George Expedition and a specialist on coral reefs, collected many coralline algae from the Galápagos, which were published on by Lemoine (1929). John Thomas Howell, a skilled botanist on board the yacht "Zaca" during the Templeton Crocker Expedition of the California Academy of Sciences in 1932, obtained significant collections of marine algae, but unfortunately they were only partly published on Setchell (1937b) and Setchell and Gardner (1937). The first phycologist to collect in the archipelago was William Randolph Taylor, operating from the "Velero III" during the Allan Hancock Pacific Expedition in January 1934. Taylor (1945) synthesized previously published information on Galápagos seaweeds together with the results of his study of collections made by the Allan Hancock Pacific Expedition of 1934 supplemented by unpublished collections made by Waldo L. Schmitt of the United States
National Museum on various other expeditions. Prior to this work, there were no published records of Codium from the islands.

Taylor recognized, based on its morphology, six species of Codium from the Galápagos, of which $C$. isabelae W. R. Taylor and $C$. santamariaeW. $\mathrm{R}$. Taylor were newly described. With the aid of numerous collections of Codium made since 1934, we have revised Taylor's treatment of the genus.

\section{MATERIALS AND METHOD}

The chief sources of specimens were the Galápagos International Scientific Project in 1964 (Bowman, 1966), the R/v Searcher expedition to the Galápagos Islands sponsored by the Janss Foundation (Thousand Oaks, California) in 1972, and the "Lost Species Expedition" sponsored by Conservation International and the National Geographic Society in 2004. These specimens are housed at the Herbarium of the University of California, Berkeley (UC). Additional specimens resulted from collecting trips sponsored by the Smithsonian Institution. Material examined covers eighty years of collecting in these islands, from 1934 to 2014. It includes dry and formalin preserved specimens.

Anatomy was studied under a Zeiss light microscope. Samples were removed from the thallus with forceps and then teased out on a slide. A cover slip was not placed on the preparation to avoid distortion of the utricles and other anatomical structures. For comparative purposes, samples were taken about $1.5 \mathrm{~cm}$ below the tip of a branch or from the center of crustose forms. Drawings were made with the aid of a camera Lucida. Digital photographs were taken with a Canon Powershot A610 camera.

\section{RESULTS}

Key to Codium species found in the Galápagos Islands based on habit

a1) Thallus prostrate, unbranched, mainly or completely adhering

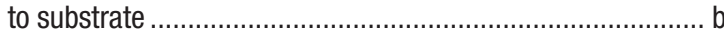

b1) Thallus $3-5 \mathrm{~mm}$ thick, spongy............................. C. arabicum

b2) Thallus 1-2 mm thick, firm ................................. . picturatum

a2) Thallus erect, dichotomously or subdichotomously

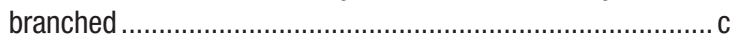

c1) Branches intertwined, some thalli with anastomosing branches ............................................................. C. isabelae

c2) Branches not intertwined .................................................. d

d1) Thallus arising from a discrete circular base, branching regularly dichotomous C. fernandezianum

d2) Thallus not arising from a discrete circular base, branching irregularly dichotomous .........................................................e

e1) Thallus arising from an elongate prostrate base, branches rough C. foveolatum

e2) Thallus with single or multiple attachments to substratum, without a prostrate base, branches smooth .C. isabelae 
Key to Codium species found in the Galápagos Islands based on anatomy

a1) Thallus dissecting out into clusters or groups of utricles.

b

b1) Tight clusters of utricles comprising primary utricles bearing secondary and tertiary utricles C. arabicum

b2) Loose groups of utricles held together by foreshortened interutricular filaments C. picturatum

a2) Thallus dissecting out into individual utricles ... C

c1) Utricles at least $900 \mathrm{~mm}$ long ... d

d1) Apical wall foveolate (pitted) C. foveolatum

d2) Apical wall not ornamented C. fernandezianum

c2) Utricles mostly less than $900 \mathrm{~mm}$ long C. isabelae

Description of species. A description of each species is presented by alphabetical order.

\section{Codium arabicum Kützing (Figs 1-3)}

Kützing 1856: 35, pl. 100: fig. II. Type: Tor, Sinai Peninsula. Gulf of Suez, Egypt (L 937.277-29).

Misidentified record: Taylor, 1945: 68 (pro parte), as C. setchellii Gardner.
Thallus dorsiventral, applanate, $3-5 \mathrm{~mm}$ thick, up to $5 \mathrm{~cm}$ in diameter, tightly adherent to the substratum but with free margins, spongy and smooth, dissecting out into tight clusters of ontogenetically related utricles. Utricles cylindrical, (40-) 50-65 (-90) $\mu \mathrm{m}$ diam., (300-) 450$700(-1,000) \mu \mathrm{m}$ long, slightly constricted in zone $65-100 \mu \mathrm{m}$ below apex, the ultimate generation of utricles often failing to produce rhizoidal filaments, Apices slightly rounded with cribrosely pitted walls, 2.5-20 $\mu \mathrm{m}$ thick. Hairs or hair scars rarely observed; when present, in a zone 90-120 $\mu \mathrm{m}$ below apex of utricle. Gametangia elliptical or fusiform, (40-) 50-70 (-100) $\mu \mathrm{m}$ diam., (180-) 200-300 (-350) $\mu \mathrm{m}$ long, borne singly or in pairs on short pedicels (250-) 300-350 (-400) $\mu \mathrm{m}$ below apex of utricle. Medullary filaments mostly 15-35 $\mu \mathrm{m}$ diam.

Habitat: Subtidal, 10-30 m depth, on rocks and corals.

All Galápagos specimens examined:

Isla Fernandina: Punta Espinosa, Searcher Stations 327 and 331, ca. 15 m depth, 25.i.1972 (UC). Isla Isabela: Punta Vicente Roca, on floor of cove, 25-55 ft (7.6- 16.8 m), M.M. Littler \& W. Gerwick, 1.ii.1978 (US Algae 026727). Isla Floreana (Santa María): Post Office Bay, dredged from 7-10 fathoms (12.8-18.3 m), W.R. Taylor 34-361, 27.i.1934, published as C. setchellii (AHFH 7179 in UC); oppressed to shells dredged from 30 fathom (55 m), W.R. Taylor 34-379C, 29.i.1934, published as C. setchellii (AHFH 7109 in UC). Isla Santa Cruz: Isla Coamano, Searcher Station 369, 14-25 m, l.ii.1972 (UC).

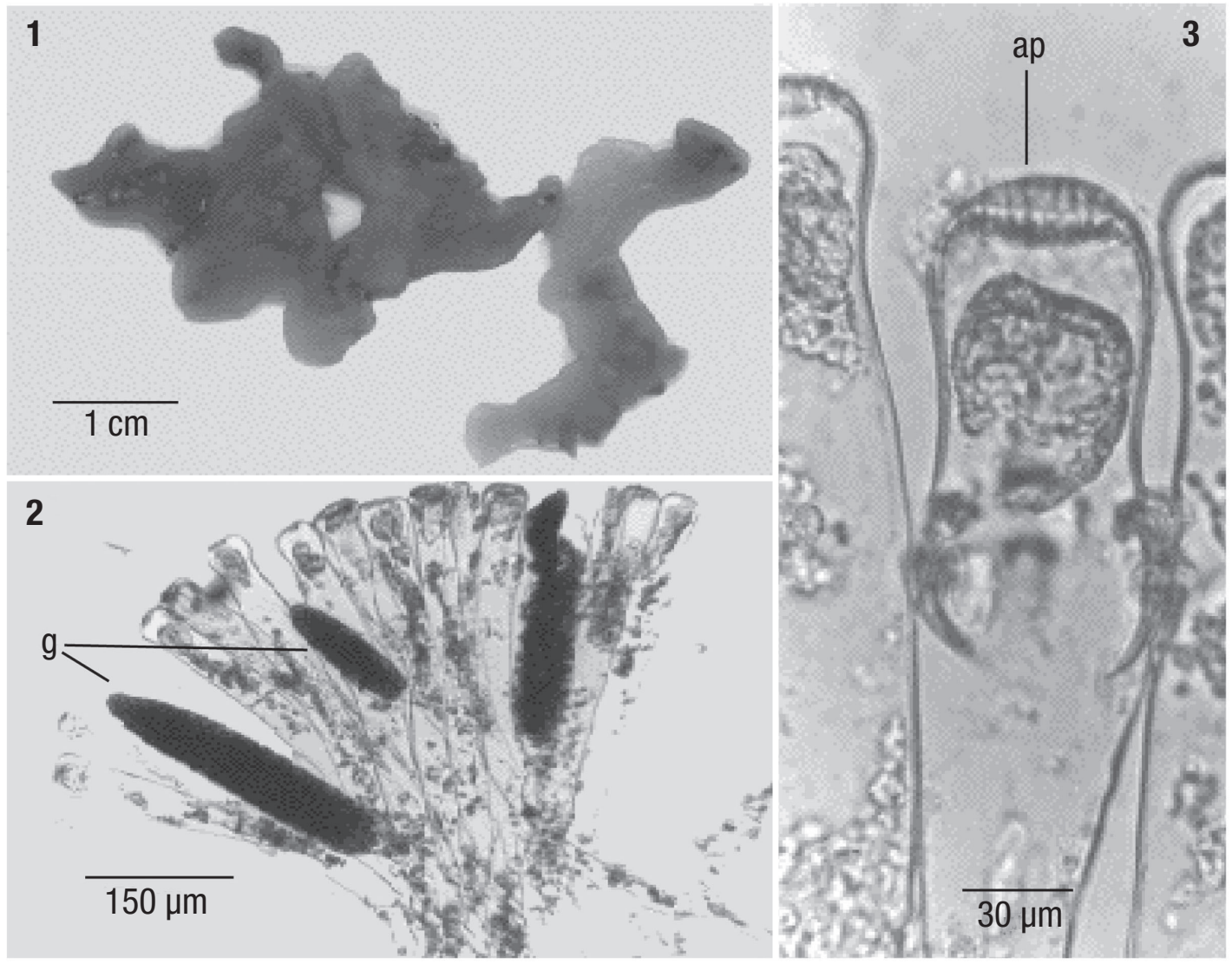

Figures 1-3. Codium arabicum. 1) Habit of a mature plant. 2) Gametangia in mature utricles. 3) Detail of the apical wall ( $g=$ gametangia, $\mathrm{ap}=$ apical wall). 


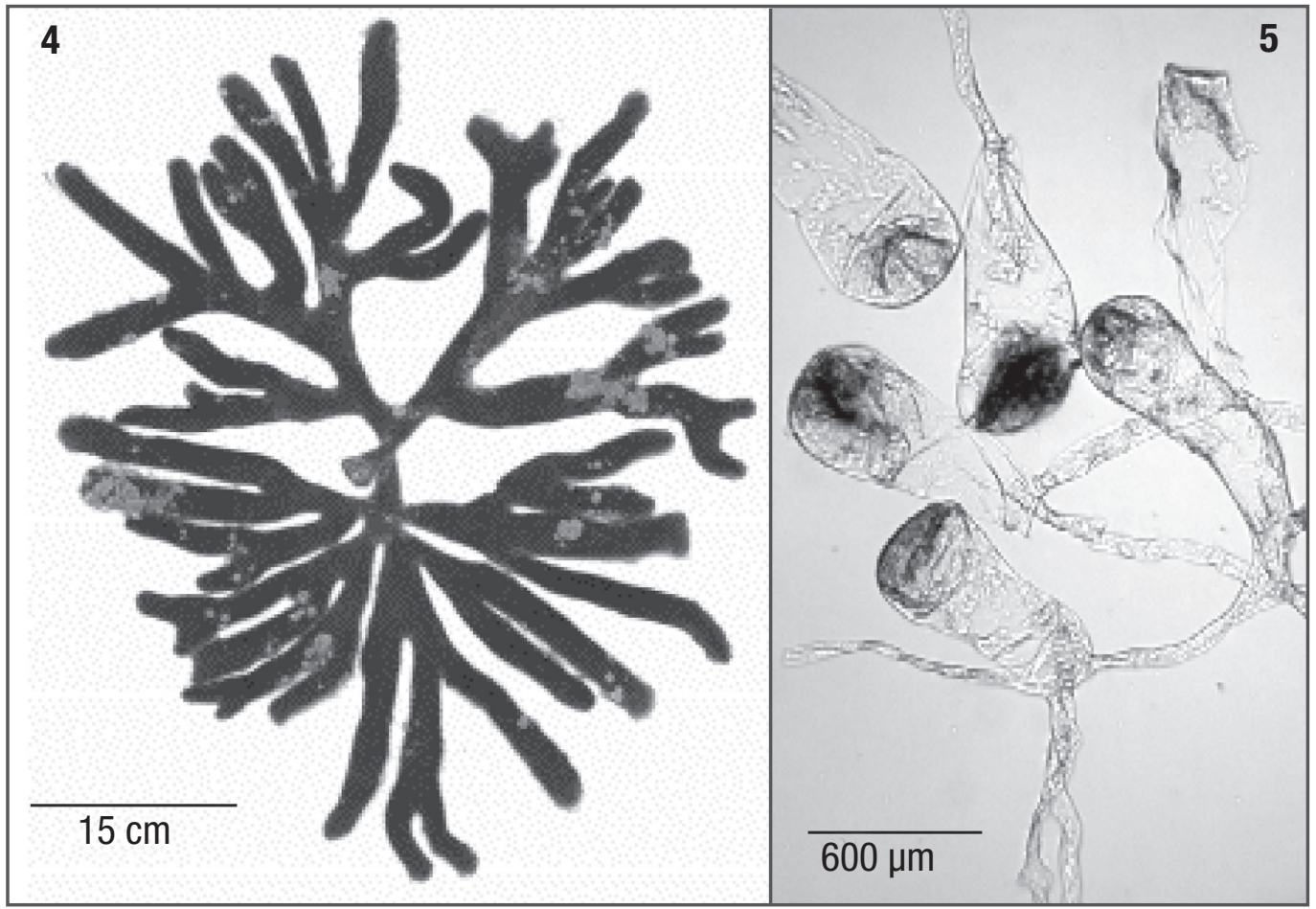

Figures 4-5. Codium fernandezianum. 4) Habit of a mature plant. 5) Immature utricles.

Local distribution: Isla Floreana (Santa María), Isla Coamano, Isla Fernandina, Isla Isabela and Isla Santa Cruz.

Distribution: Indo-Pacific, Islas Galápagos.

Codium arabicum as circumscribed by Silva (1952) encompasses populations with applanate thalli occurring throughout warm waters of the Indo-Pacific region, from the west, Red Sea (type locality), to the east on the Hawaiian Islands. These populations exhibit significant anatomical variability, but it has not been possible to establish correlations between morphotypes and geographic areas. The entire range of variability can be found within the Hawaiian Islands.

This is the first record of Codium arabicum from the East Pacific: always subtidal, it grows in three islands of the Galápagos Archipelago. We refer to this complex species a few specimens of an alga that lacks of features that would warrant description of a new species or unequivocally relate it to previously recognized species. Morphological and anatomical characters from specimens belonging to Galápagos are not completely similar with the typical $C$. arabicum concept. The specimens studied have a smoother texture, indicating utricles not well compacted. The apices have deeper cribosely pitted walls than typical C. arabicum. The color also is different, in the Galápagos the thalli are light green while in the Indo-Pacific material the thalli are deep green. Although molecular data are available for populations from the IndoPacific region that have been assigned to $C$. arabicum, none exist for the Galápagos population so that a confirmatory comparison in molecular terms is not possible. Nonetheless, because utricular morphology in the Galápagos specimens is readily accommodated by the current circumscription of $C$. arabicum, we believe that referring them to that species is the most reasonable course of action.
Throughout the Indo-Pacific region, $C$. arabicum occurs commonly in shallow water, although it also grows at depths as great as $24 \mathrm{~m}$. In the Galápagos, by contrast, intense irradiation of the black lava in shallow water produces an inhospitable habitat for all but a few organisms (Hedgpeth, 1969). The four known collections were all made subtidally. Considering that several persons proficient both in diving and in marine phycology have engaged in surveys throughout the Galápagos, it seems reasonable to assume that the paucity of records of $C$. arabicum reflects its scarcity.

\section{Codium fernandezianum Setchell (Figs 4-5)}

Setchell 1937a: 592, pls. 35-38, figs. 5-15; pls. 41-48. Type: Is. Juan Fernández. H. N. Moseley, s.n. xii.1875. Challenger expedition Kew 73 (BM 000516154).

Thallus dark green, erect, dichotomously branched; to $40 \mathrm{~cm}$ high with distinctive holdfast; branches terete, slightly compress and cuneate at dichotomies. Medullary filaments $30-55 \mu \mathrm{m}$ diam. Utricles cylindrical to clavate, (1 000-) 1 200-1 400 (-1 500) $\mu \mathrm{m}$ long, (180-) 300-500 $(-550) \mu \mathrm{m}$ diam. Apices rounded or truncate. Hairs and scars present in a zone 230-350 $\mu \mathrm{m}$ from the apex. Gametangia lanceolate or ovoid, (280-) 310-400 (-450) $\mu \mathrm{m}$ long, (110-) 130-150 (-160) $\mu \mathrm{m}$ diam. One to three gametangia per utricle, borne on short pedicel, 500-630 $\mu \mathrm{m}$ below apex of utricle.

Habitat: Intertidal over rocks in quiet waters.

Representative Galápagos specimens examined: 
Isla Santa Cruz: Academy Bay, E.Y. Dawson 22204, 19.ii.1962 (US 59559), E.Y. Dawson 22204, 19.ii.1962 (US 4863); Tortuga Bay, E.Y. Dawson 22386, 9.iii.1962 (US 5048).

Local distribution: Isla Santa Cruz.

Distribution: Isla Juan Fernández, Peru, Ecuador, Islas Galápagos.

Codium fernandezianum is a closely related species to $C$. decorticatum (Woodward) Howe from Caribbean, Atlantic and Mediterranean, C. duthieae P.C. Silva from southern Australia and South Africa, C. cylindricum Holmes from Japan and $C$. amplivesciculatum Setchell \& Gardner from Gulf of California. These species have subtle differences in gross morphology and anatomical measurements. In the Galápagos, this species has been found only in quiet waters, comparing the gross morphology of the specimen collected by Skottsberg at Juan Fernández Island where the thalli are less branched and with thicker apical wall, these morphology and anatomical characteristics also have been observed in material from Peru and Ecuador.

\section{Codium foveolatum Howe (Figs 6-7)}

Howe 1914: 45, pl. 10, text fig. 15.19. Type: Lobos de Tierra, Peru. Coker 150b, 2.iv.1907 (N\# 150B).

Thallus dark green, erect, decumbent, irregularly dichotomously branched with anastomosis, terete; to $10 \mathrm{~cm}$ high; branches 3-8 $\mathrm{mm}$ diam., slightly compress at dichotomies. Medullary filaments 50-85 $\mu \mathrm{m}$ diam. Utricles cylindrical to clavate, frequently with slight constriction just below apex, (900-) 1 000-1 300 (-1 500) $\mu \mathrm{m}$ long, (350-) 400-500 (-600) $\mu \mathrm{m}$ diam. Apices slightly rounded or subtruncate, apical walls foveolate, papillate or cribosely pitted. Hairs and scars absent. Gametangia ovoid or fusiform, (300-) 350-450 (-500) um long, (35-) 40-60 (-70) $\mu \mathrm{m}$ diam., one to three per utricle, borne on short pedicel $600-730 \mu \mathrm{m}$ below apex of utricle.
Habitat: Subtidal, 1-54 m depth, on rocks.

Representative Galápagos specimens examined: Isla Coamano: Search Station \# 369. Isla Fernandina: Punta Espinosa, Search Station \# 331. Isla Isabela: Tagus Cove, dredged in 15-30 fms (27-54 m), 13.i.1934, W.R. Taylor 34-140 (AHFH in UC, MICH), US 026753; Caleta Iguana 3.xii.2004 50-70' K.A. Miller 08-119. Isla Santa Cruz: Academy Bay, Search Station \# 363. Isla Floreana (Santa María): Black Beach, of dwarfed habit, confined to the deeper tide pools, 17.i.1934, W.R. Taylor 34-244C (AHFH in UC, MICH); Post Office Bay, dredged in $15 \mathrm{fms}$ (27m), 19.i.1934, W.R Taylor 34-276B (AHFH in UC, MICH). Isla Española: dredged from 37m, W.L. Schmitt 362A-35, 19.xii.1934 (MICH) not cited by Taylor! see W.R. Taylor 42.

Local distribution: Isla Coamano, Isla Fernandina, Isla Isabela, Isla Santa Cruz, Isla Floreana (Santa María), Isla Española.

Distribution: Peru, Islas Galápagos.

Codium foveolatum was described by Howe in 1914, using a specimen collected from Isla Lobos de Tierra, Peru (Dawson et al., 1964). Nobody has ever found again this species in the type locality; however is well distributed among Galápagos Islands. This species could be endemic of the islands and just some thalli reached the continent by dispersion, but Peruvian an Ecuador coasts have not been survey extensively because topographic difficulties. Utricles with foveolate apices make this species very distinctive.

\section{Codium isabelae W. R. Taylor (Figs 8-9)}

Taylor 1945: 70, pl. 1: figs. 10-13; pl. 7: fig. 1. Type: Tagus Cove, Isla Isabela, Galápagos Islands, W.R. Taylor 34-152, 14.i.1934 (AHFH 131 in UC).

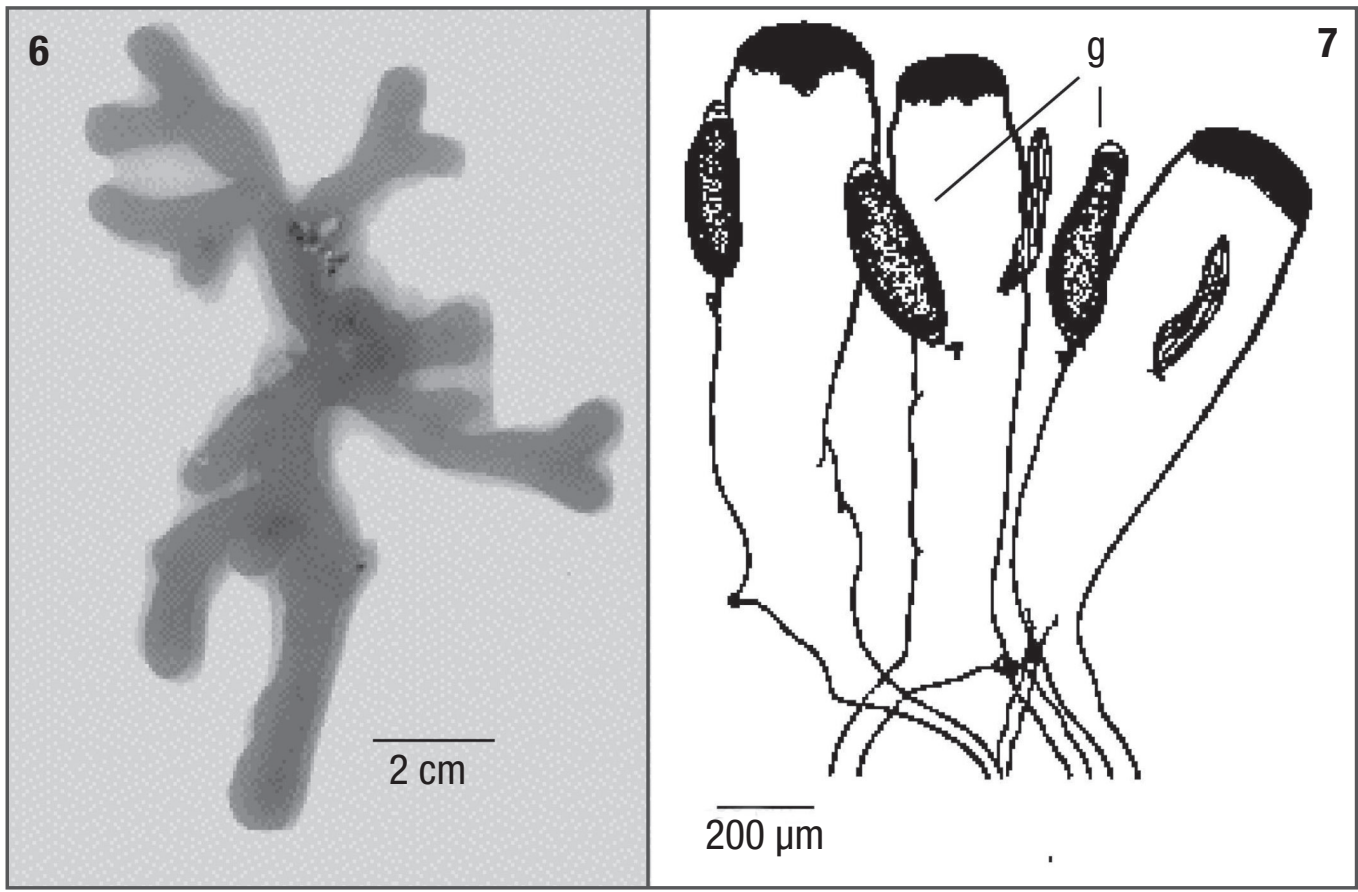

Figures 6-7. Codium foveolatum. 6) Habit of a mature plant. 7) Gametangia in mature utricles. 
Heterotypic synonym: Codium santamariae W.R. Taylor 1945: 69, pl. 1: figs. 14-16. Type: Black Beach Anchorage, Isla Santa María [Floreana], Galápagos Islands, W.R. Taylor 34-226, 17.i.1934 (AHFH 132 in UC).

Misidentified records from the Galápagos: Taylor, 1945: 69, as C. cervicorne; Taylor, 1945: 68 (Galápagos collection only), as Codium dichotomum.

Thallus light to dark green, decumbent, irregularly dichotomously branched with anastomosis, terete or compress; to $10 \mathrm{~cm}$ high. Medullary filaments $15-30 \mu \mathrm{m}$ diam. Utricles cylindrical to clavate, slight constriction just below apex, (350-) 400-550 (-630) um long, (55-) 65-90 $(-110) \mu \mathrm{m}$ diam. Apices rounded or truncate, apical walls lamellate up to $15 \mu \mathrm{m}$ thick. Hairs and scars common in a zone 50-100 $\mu \mathrm{m}$ from the apex. Gametangia ovoid or fusiform, (150-) 170-200 (-210) $\mu \mathrm{m}$ long, (40-) 55-70 (-80) $\mu \mathrm{m}$ diam., one to three per utricle, borne on short pedicel, 220-290 $\mu \mathrm{m}$ below apex of utricle.

Habitat: Intertidal and subtidal, up to $77 \mathrm{~m}$ depth.

Representative Galápagos specimens examined:

Isla Fernandina: Punta Espinosa, 30' depth, K.A. Miller 14-215, 30.ix.2004 (UC); islet south of Cabo Douglas, 60-75' depth, K.A. Miller 12-198, I.xii.2004 (UC). Isla Isabela: Tagus Cove, rocks at low tide, W.R. Taylor 34-152, 14.i.1934, HOLOTYPE of $C$. isabelae (AHFH 131 in UC); Caleta Iguana, 50-70' depth, K.A. Miller 08-118, 3.xii.2004 (UC). Isla Santa Cruz: Tortuga Bay, growing around mangrove roots in high intertidal pool, S.A. Earle 66100, 18.v.1966; Darwin Research Station, on lava rock, ca. $1 \mathrm{~m}$ depth, D.P. Abbott, 25.i.1964 (UC); rocks in quiet water at lowest intertidal zone, P.C. Silva 7568, 29.i.1964 (UC); Puerto Nuñez, in tide pool, S.A. Earle 66120, 21.v.1966 (UC). Isla Santa Fe: Punta Pingüina, 95' depth, K.A. Miller 01-001, I.xii.2004 (UC). Isla Floreana (Santa María): Black Beach Anchorage, W.R. Taylor 34-226, 17.i.1934, HOLOTYPE of $C$. santamariae (AHFH 132 in UC); Post Office Bay, dredged from 15 fathom (27.4 m), W.R. Taylor 34-273, 19.i.1934, as C. dichotomum (AHFH 589 in UC). Isla Española: near an islet in Gardner Bay, dredged from rocky bottom at 20-30 fathoms (36.6-54.9 m), W.R. Taylor 34-420, 31.i.1934 (AHFH 7108 in UC); same data, W.R. Taylor 34-424, as C. cervicorne (AHFH 7118 in UC).

Local distribution: Isla Fernandina, Isla Isabela, Isla Santa Cruz, Isla Santa Fe, Isla Floreana (Santa María), Isla Española.

Distribution: Ecuador, Islas Galápagos.

Comparison of the description of Codium isabelae with that of $C$. santamariae reveals slight differences, which disappear completely when a spectrum of examples is examined. Writing about $C$. santamariae, Taylor summarized the perceived differences as follows: "These plants resemble $C$. isabelae except for the thin-walled vesicle tips and somewhat smaller gametangia." In the description of $C$. santamariae the utricle apices are said to be "3-6 $\mu \mathrm{m}$, rarely to $17 \mu \mathrm{m}$ thick", whereas those in $C$. isabelae are said to be "notably thick and lamellate, 15-35 $\mu \mathrm{m}$ ". An examination of many thalli failed to reveal any taxonomically usable pattern in apical wall thickening. There is an overlap in the size ranges of gametangia given in the descriptions.

As recently as 2004, Kathy Ann Miller found that this dichotomously branched species was abundant throughout the Galápagos but that the habit was highly variable. In shallow water the thalli tended to be prostrate and matted whereas those from deeper water tended to be erect and freely branched. Considering all specimens available for study, most axes remain slender (3-5 $\mathrm{mm}$ diam.), but thalli from the Darwin Research Station were complanate and up to $12 \mathrm{~mm}$ wide.

In the late 1970s, when phycologists at the Universidad Nacional Autónoma de México and the Instituto Politécnico Nacional began an intensive study of the algae from tropical shores of Mexican Pacific, a small, procumbent, basally anastomosing Codium was frequently encountered in intertidal pools. Mexican authors under several different names reported this alga: $C$. decorticatum, $C$. dichotomum S.F. Gray, $C$. edule P.C. Silva, C. geppiomm 0.C. Schmidt, C. isthmocladum Vickers.

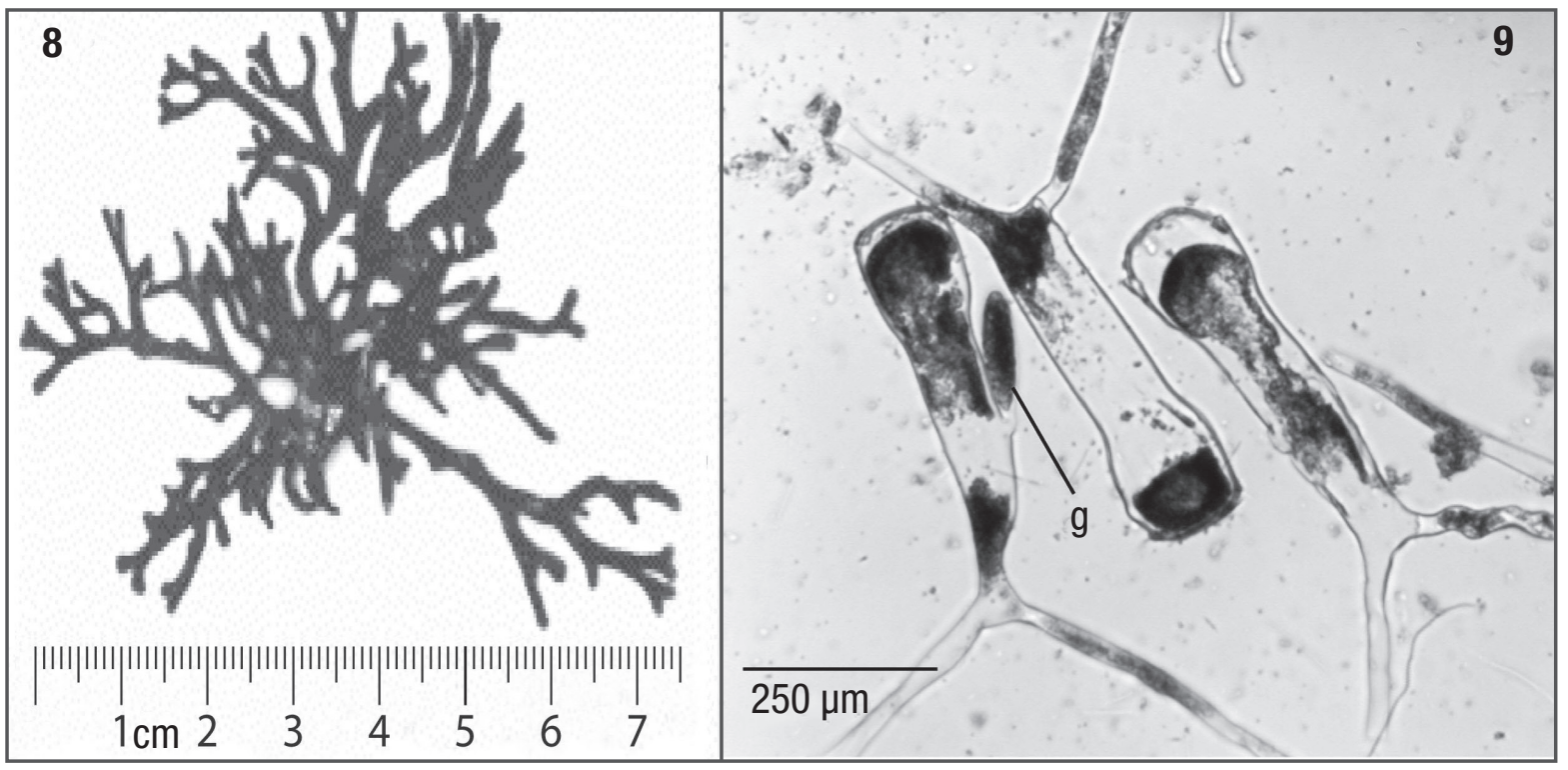

Figures 8-9. Codium isabelae. 8) Habit of a mature plant. 9) Gametangia in mature utricles. 
While undertaking a monographic study of Mexican Codium, Pedroche realized that the alga in question did not belong to any of those species and gave it a tentative name, C. oaxacense illeg. (Pedroche, 1998: 61). After studying Galápagos Codium, it became clear that this Mexican species was closely related if not identical to $C$. isabelae (Pedroche, et al., 2005: 52). Taylor (1945: 59) had previously reported $C$. isabelae from the mainland (Punta Santa Elena, Guayas Province, Ecuador). CoIlections from El Salvador recorded by Dawson (1961: 406, pl. 3: fig. 4) almost certainly are referable to $C$. isabelae, although a confirmatory examination of the specimens has not been made. In the present paper, we treat the mainland and Galápagos populations as conspecific.

\section{Codium picturatum F.F. Pedroche et P.C. Silva (Figs 10-12).}

Pedroche \& Silva, 1996: 2, figs. 1-6. Type: Playa La Audiencia (near Manzanillo), Colima, Mexico, on rocks exposed at low tide in moderate surf, Pedroche et al. FP12ne, 22.iii.1991 (MEXU).

Previous record from the Galápagos: Pedroche and Silva, 1996: 4. Misidentified record: Taylor, 1945: 68 (pro parte), as C. setchellii.

Thallus applanate, very thin (1-2 mm thick), closely adherent to the substratum throughout (including margins), forming an irregularly shaped smooth layer, deep green, dissecting out into loose groups of utricles held together by foreshortened interutricular filaments, Utricles very slender, subcylindrical or slightly clavate, (38-) 55-85 (-125) $\mu \mathrm{m}$ diam., (270-) 400-900 (-1200) $\mu \mathrm{m}$ long, arising as outgrowths of existing utricles or medullary filaments, often with a plug at the base and without rhizoidal filaments. Medullary filaments scanty, 20-35 $\mu \mathrm{m}$ diam. Apices rounded with thin walls, at most ticked to $2.5 \mu \mathrm{m}$. Hairs or hair scars sometimes present in a zone 40-160 $\mu \mathrm{m}$ below apex of utricle. Gametangia fusiform, (35-) 48-78 (-90) um diam., (140-) 160-240 $(-270) \mu \mathrm{m}$ long, borne singly on short pedicel (190-) 230-335 (-365) $\mu \mathrm{m}$ below apex of utricle.

Habitat: Intertidal and subtidal, 1-60 m depth, over rocks and corals.

Representative Galápagos specimens examined:

Isla Isabela: Punta Vicente Roca, K. A. Miller, on barnacles at 15-21 ft (4.6-6.4 m) depth, 29.xi.2004 (UC). Isla Santiago (James): Sullivan Bay, Searcher Station 353, 37 m depth, 29.i.1972 (UC). Isla Rabida: Searcher Station 344, 5-20 m, 27.i.1972 (UC). Isla Pinzón: Searcher Station 350, abundant on boulders at 5-8 m depth, 28.i.1972 (UC). Isla Daphne: Searcher Station 356, on side of rocky drop off at $15 \mathrm{~m}$ depth, 30.i.1972 (UC). Isla Seymour: Searcher Station 359, encrusting rocks at 5-15 m

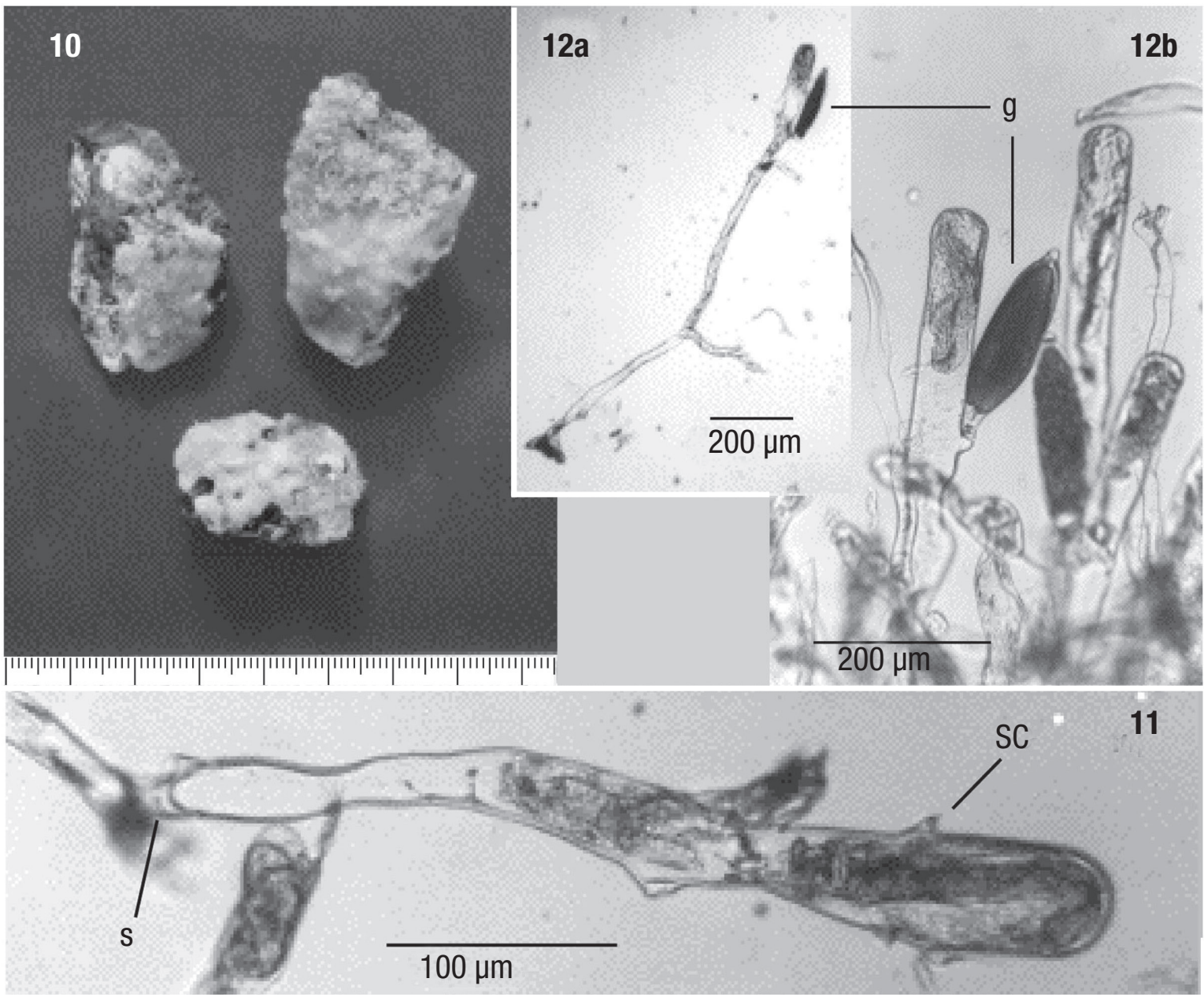

Figures 10-12. Codium picturatum. 10) Habit of a mature plant. 11) Utricle with basal septum and hair scars. 12a) Utricle with gametangium and medullary filament showing attaching terminal point to substratum. $12 \mathrm{~b}$ ) Detail of gametangia ( $s=$ septum, $g=$ gametangia, $s c=s c a r)$. 
depth, 30.i.1972 (UC). Isla Santa Cruz: 1 mi. E of Darwin Research Station, E. Y. Dawson and C.M. Dawson 22258, intertidal, 8.iii.1962 (US Algae 59671); mouth of Academy Bay, Searcher Station 371, on large rocks at 10m depth, 1.ii.1972 (UC); midway between Punta Estrada and Isla Coamano, Searcher Station 366, on coralline rubble, 30-33 m, 31.i.1972 (UC). Isla Santa Fe (Barrington): Searcher Station 360, 27m depth, 30.i.1972 (UC); on stony coral, 3 fms (5.4 m) depth, W.L. Schmitt 46A-33, 2.ii.1933, published by W.R. Taylor as C. setchellii prox., incorrectly stated to be from Isla Pinta (MICH). Isla Floreana (Santa María): Black Beach Anchorage, Searcher Station 315, ca. 15m depth, 23.i.1972 (UC); W.R. Taylor 34-242, 19.i.1934, published as C. setchellii (AHFH 0000 in UC). Isla Marchena: Punta Espejo, US 026772 Muller and Salazar, 1996: 46, as C. setchellii.

Local distribution: Isla Isabela, Isla Santiago (I. James), Isla Rabida, Isla Pinzón, Isla Daphne, Isla Seymour, Isla Santa Cruz, Isla Coamano, Isla Santa Fe (Barrington), Isla Pinta, Isla Floreana (Santa María), Isla Marchena.

Distribution: Hawaii, Gulf of California, Tropical Mexican Pacific to Islas Galápagos.

After studying specimens from the Galápagos and Panama, that Taylor considered to be thin thalli of $C$. setchellii, Silva (1951: 84-85) concluded that they represented "one or more quite different species". One collection cited by Silva (1951) (W.R. Taylor 34-379c from Isla Floreana) is referred in the present paper to $C$. arabicum whereas two others (W.R. Taylor 34-242 from Isla Floreana and W.R. Taylor 34-508 from Isla Jicarita, Panama) proved to represent this new species, $C$. picturatum. Dawson (1959) observed or collected thin adherent thalli of Codium at several localities in the southern Gulf of California. Pedroche and González González (1981) reported a thin adherent species (as C. sp.) from the state of Jalisco on the Mexican mainland. Schnetter and Bula Meyer (1982) described and illustrated thin adherent thalli of an unnamed Codium from Isla Gorgona near the Pacific coast of Colombia. With numerous suspiciously similar collections available for study, Pedroche and Silva (1996) determined that all were representative of a single previously undescribed species, which they named $C$. picturatum. The epithet, meaning "painted" in Latin, refers to the very thin thallus which appears to be painted on the substratum.

Codium picturatum is a distinctive species in which the applanate thallus is nearly devoid of a medulla and secondary utricles arise from existing utricles or from filaments directly (without intervention of an interutricular filament) so that many utricles have basal plugs. When publishing C. picturatum, Pedroche and Silva (1996) cited two collections from the Galápagos. After attention was focused on the marine algae of those islands, it was realized that this species had been observed and collected at numerous sites by Sylvia Earle, the leader of the scientific team of the Janss Expedition in 1972.

\section{DISCUSSION}

Above we have already mentioned some remarks concerning each one of the species. Here, we will give a brief discussion concerning to $\mathrm{Co}$ dium in general terms but mainly related with insular environments.

As we have seen before in morphological terms Codium, as a genus, presents a reduced number of characters that related with its phe- notypic plasticity make some of the taxonomic considerations not applicable. Similarity or resemblance of gross morphology or even in utricle anatomy confuses untrained biologists consequently erroneously giving records of species that could not be present in certain geographical areas, at least not naturally. Furthermore, Codium fernandezianum is closely related, in morphological terms, with $C$. decorticatum from the Atlantic, Caribbean and Mediterranean seas. Codium duthieae from Australia and Sudafrica, C. cylindricum a japanese species, and $C$. amplivesciculatum from the Gulf of California are very similar, big thalli with huge utricles.

Codium arabicum populations apparently grow in warm waters of Indo-Pacific and Hawaiian islands. How these species are related, in origin and evolution with those applanate representatives from other parts of the world is an interesting question to solve in the near future. Evidence shows applanate thalli are monophyletic (Pedroche, 2001).

Island species as Codium foveolatum need special consideration; some of them are presumably endemic to those environments however several that originally we thought were restricted to islands are in continental coasts. Did they disperse over time? or because they were discovered and described first on islands, were they assumed endemic to them?. On the other hand, Codium isabelae and C. picturatum described for the continent, are recorded from islands (see above) surely they reached these by dispersion. Local studies with molecular tools will give us definitive answers about the evolutionary history of these organisms and others giving us the opportunity to build hypothesis on their origin and distribution.

So, islands are the best spaces for studying local distribution, dispersion, endemism and evolutionary pathways in algae and other organisms. Differentiated isolation processes, between them and continents are natural experiments by themselves. However to have a better and complete view, a detail comparative study with morphological and molecular information, among specimens from nearby continental areas is needed.

Environmental factors, microhabitats, predators, weather in general combined with ocean currents, as well as depth and distance among and between land bodies are determinant in presence or absence of certain species.

\section{ACKNOWLEDGMENTS}

We wish to express our thanks to J.N. Norris, curator of the Phycology section at US for his help. F.F. Pedroche wants to thank CONACyT, OEA and UAM-Iztapalapa for their financial support during his stay in UCBerkeley, through a postgraduate scholarship.

\section{REFERENCES}

Bowman, R. (ed.) 1966. The Galápagos; Proceedings of the Symposia of the Galápagos International Scientific Project. University of California Press, Berkeley. 319 pp.

Dawson, E. Y. 1959. Marine algae from the 1958 cruise of the Stella Polaris in the Gulf of California. Los Angeles County Museum Contributions in Science 27: 39 p., 39 Figs. 
Dawson, E. Y. 1961. Plantas marinas de la zona de las mareas de El Salvador. Pacific Naturalist 2 (8): 389-461, 337 Pls.

Dawson, E. Y., C. Acleto \& N. Foldvik. 1964. The seaweeds of Peru. Nova Hedwigia 13: 111 pp., 181 láms.

Farlow, W. G. 1902. Algae. In: B.L. Robinson. Flora of the Galápagos Islands. Proceedings of the American Academy of Arts and Sciences 38: 89-99.

FosLIE, M. 1907. Algologiske notiser III. Botanische Jahrbücher für Systematik, Pflanzengeschichte und Pflanzengeographie 28: 529-545, PI. XI.

Harvey, W. H. 1847-1849. Nereis australis ... London. viii + 124 pp. Pls. [Pp. [i]-viii + [121]-164, Pls. I-XXV (1847); pp. 1865-1124, Pls. XXVI-L (1849)].

HedGPETH J. W. 1969. Distribution of selected groups of marine invertebrates in waters south of $35^{\circ} \mathrm{S}$ latitude. Introduction to Antarctic Zoogeography. Antarctic Map Folio Series-Folio 11: 1-8.

Heydrich, F. 1901. Die Lithothamnien des Museum d'histoire naturelle in Paris. Kongelige Norske Videnskabers Selskabs Skrifter 1906 (8): $1-34$.

Howe, M. A. 1914. The marine algae from Peru. Memoirs of the Torrey Botanical Club 15: 1-185, 166 Pls., 144 Figs text.

KützING, F. T. 1856. Tabulae phycologicae ... Vol. 6. Nordhausen. IV + 35 pp., 100 Pls.

Lemoine, Mme P. 1929. Les Corallinacées de l'Archipel des Galápagos et du Golfe de Panama. Archives du Muséum d'Histoire Naturelle [Paris], series 6, 4: 37-88, 35 Figs, IV Pls.

Pedroche F. F. 1998. El género Codium (Chlorophyta) en el Pacífico de México. Tesis de Doctorado. Facultad de Ciencias, UNAM, México. 129 p., 125 Figs.

Pedroche, F. F. 2001. Estudios filogenéticos del género Codium (Chlorophyta) en el Pacífico Mexicano. Uso de ADNr mitocondrial. Anales de la Escuela Nacional de Ciencias Biológicas 47 (1): 109-123.

Pedroche, F. F. \& J. González-González. 1981. Lista florística preliminar de las algas marinas de la región sur de la Costa de Jalisco, México. Phycologia Latino-Americana 1: 60-71, 1 Fig.

Pedroche, F. F. \& P. C. Silva. 1996. Codium picturatum sp. nov. (Chlorophyta), una especie extraordinaria del Pacífico Tropical Mexicano. Acta Botánica Mexicana 35: 1-8, 6 Figs.
Pedroche, F. F., P. C. Silva \& M. Chacana. 2005. El género Codium (Codiaceae, Chlorophyta) en el Pacífico de México. Monografias Ficológicas 1: 1-64, 89 Figs.

Piccone, A. 1886. Alghe del viaggio di circumnavigazione della Vettor Pisani. Genova. 97 p., II Pls.

PICCone, A. 1889. Nuove alghe del viaggio di circumnavigazione della "Vettor Pisani". Atti della Reale Accademia dei Lincei, Memorie di Classe di Scienze. Fisiche, Matematiche e Naturale, series 4, 6: 10-63.

Setchell, W. A. 1937a. The Codiums of the Juan Fernandez Islands. In: C. Skottsberg (Ed.). The natural history of Juan Fernandez and Easter Island.. Uppsala. 2: 587-600, Pls. 534-548.

SetchelL, W. A. 1937b. The templeton Crocker expedition of the California Academy of Sciences, 1932. $N^{0} 34$. Report on the Sargassums. Proceedings of the California Academy of Sciences, ser. 4, 22 (5): 127-158, Pls. 128-133.

Setchell, W. A. \& N. L. Gardner. 1937. The templeton Crocker Expedition of the California Academy of Sciences, 1932. № 31. A preliminary report on the algae. Proceedings of the California Academy of Sciences: ser. 4, 22: 65-98, Pls. 23-25, 21 text Fig.

Schnetter, R. \& G. Bula Meyer. 1982. Marine algen der Pazifikkuste von Kolumbien. Chlorophyceae, Phaeophyceae. Bibliotheca Phycologica 60: XVII + 287 pp., XXXVII Pls., 281 Figs.

SılvA, P. C. 1951. The genus Codium in California with observations on the structure of the walls of the utricles. University of California Publications in Botany 25 (2): 79-114, Pls. 111-116, 132 Figs.

SILvA, P. C. 1952. Codium. In: L. E. Egerod. An analisis of the siphonous Chlorophycophyta with special reference to the Siphonocladales, Siphonales and Dasycladales of Hawaii. University of California Publications in Botany 25: 381-395, Figs. 311-318, Pls. 334b, $335,336$.

TAYLOR, W. R. 1945. Pacific marine algae of the Allan Hancock Expeditions to the Galápagos Islands. Allan Hancock Pacific Expeditions 12: iv + 528 pp., 523 Figs., 100 Pls.

Recibido: 12 de marzo de 2015.

Aceptado: 26 de noviembre de 2015. 